\title{
TINGKAT USABILITAS DAN KEPUASAN EVERNOTE SEBAGAI PLATFORM E-LEARNING UNTUK MATA KULIAH ILMU DASAR KEPERAWATAN DI FAKULTAS KEPERAWATAN UNIVERSITAS PADJADJARAN
}

\author{
${ }^{1}$ Ryan Hara Permana, ${ }^{2}$ Irfan Ardiansah, ${ }^{3}$ Dian Adiningsih, ${ }^{4}$ Mira Trisyani \\ ${ }^{1,3,4}$ Fakultas Keperawatan, Universitas Padjadjaran \\ ${ }^{2}$ Fakultas Teknologi Industri Pertanian, Universitas Padjadjaran \\ E-mail: ryan.hara@unpad.ac.id
}

\begin{abstract}
Abstrak
Evernote adalah aplikasi yang dapat digunakan sebagai platform e-learning alternatif untuk pendidikan tinggi. Namun, belum diketahui tingkat usabilitas dan kepuasannya pada pendidikan keperawatan di Indonesia. Penelitian ini menginvestigasi tingkat usabilitas dan kepuasan Evernote sebagai platform e-learning. Metode yang digunakan adalah survei menggunakan kuesioner dengan teknik purposive sampling. Responden adalah 139 mahasiswa Fakultas Keperawatan, Universitas Padjadjaran yang mengikuti online course Ilmu Dasar Keperawatan versi trial. Data tendensi sentral (mean) dianalisis untuk setiap item dan setiap kategori. 'Rerata usabilitas' dan kepuasan terhadap 'desain' dinilai cukup baik (69,2\% dan 77\%), namun kategori 'reliabitas sistem', dan 'hasil dan penggunaan di masa depan' masih dinilai rendah (56,5\% dan 56,4\%). Ini menunjukkan bahwa aplikasi Evernote diminati oleh mahasiswa namun mereka belum dapat melihat kemanfaatannya dalam belajar karena penelitian dilakukan pada mata kuliah online versi trial. Penelitian lebih lanjut diperlukan dengan implementasi Evernote pada mata kuliah yang terintegrasi dengan kurikulum, dan didukung dengan tahap persiapan yang komprehensif.
\end{abstract}

Kata kunci: E-learning, Keperawatan, Kepuasan, Usabilitas, Platform, Pendidikan

\begin{abstract}
Evernote is an application used as an alternative e-learning platform for higher education. However, the level of usability and satisfaction in nursing education in Indonesia, still unknown. This research investigates the level of usability and satisfaction of Evernote as an e-learning platform. A questionnaire survey method was used, with purposive sampling technique. The respondents were 139 students of Faculty of Nursing, Universitas Padjadjaran who attended the trial version of Basics Nursing Science online course. The central tendency (mean) of the data was analyzed for each item and each category. The 'average usability' and satisfaction with the 'design' are considered to be quite good (69.2\% and 77\%), but the 'system reliability' category, and 'outcome and future use' perceived as low (56.5\% and $56.4 \%)$. Study findings indicate that the Evernote application is in demand by the students, but they have not been able to feel its usefulness in learning as the research was conducted on the trial version of the online course. Further research is needed with the implementation of Evernote in courses integrated with the curriculum and supported by a comprehensive preparation stage.
\end{abstract}

Keywords: E-learning, Nursing, Satisfaction, Reusability, Platform, Education

\section{PENDAHULUAN}

Penggunaan metode e-learning, baik blended maupun full online sangat diperlukan terutama untuk pendidikan keperawatan di Indonesia. Terdapat kurang lebih 288 institusi pendidikan keperawatan di Indonesia yang menyelenggarakan pendidikan keperawatan termasuk jenjang pendidikan Diploma Tiga (DIII), Sarjana (S1), Ners (Ns), Magister dan doktoral keperawatan (AIPNI, 2017). Kementerian pendidikan dan kementerian kesehatan Republik Indonesia telah melakukan upaya untuk meningkatkan kualitas pendidikan keperawatan melalui penyelenggaraan sistem akreditasi dan penyelenggaraan ujian akhir kompetensi lulusan perawat. Hal tersebut memberikan pengaruh bagi institusi pendidikan di Indonesia untuk mampu dalam melakukan 
pengembangan dan peningkatan kualitas mutu pendidikan di institusi masing-masing. Namun, masih dirasakan keterbatasan dukungan terhadap peningkatan proses pembelajaran tersebut yang belum sesuai dengan harapannya saat ini.

Sebagai negara kepulauan, penggunaan $e$ learning dapat digunakan sebagai salah satu alternatif untuk penyelenggaraan pendidikan khususnya bagi institusi keperawatan di seluruh wilayah Indonesia. Kemenristekdikti pun telah mengembangkan pembelajaran online ini sejak tahun 2014 melalui program yang saat ini disebut Sistem Pembelajaran Daring (SPADA) Indonesia (Kemenristekdikti, 2016). Universitas Padjadjaran juga mendukung implementasi $e$ learning pada pendidikan keperawatan dengan meluncurkan program Pendidikan Jarak Jauh (PJJ) dan Open Online Course pada 2 Mei 2018 (Maulana \& Siswandini, 2018).

Keberhasilan pelaksanaan e-learning dan pembelajaran blended sangat tergantung dari usabilitas platform yang digunakan (Singh, 2003). Usabilitas didefinisikan sebagai kemampuan sistem untuk memfasilitasi pengguna mencapai tujuannya dengan mudah dalam konteks penggunaan yang spesifik (Coursaris \& Kim, 2011). Sebuah platform elearning harus dapat mendukung interaksi antara pengguna dan sistem, mampu memotivasi pengguna, dan tidak menghambat alur pembelajaran (Ardito et al., 2004; Cho, Cheng, \& Lai, 2009).

Evernote adalah salah satu aplikasi web yang dapat dijadikan alternatif pilihan sebagai platform e-learning. Evernote bersifat tidak berbayar (freemium) dan mudah diakses secara online pada aplikasi iOS dan Android, juga secara offline dengan instalasi pada desktop/laptop. Evernote sangat berpotensi digunakan sebagai platform e-learning karena merupakan aplikasi catatan (notes) berbasis website yang mudah dibagikan (Dotto, 2015), meningkatkan keterlibatan dalam belajar dan memfasilitasi pembelajaran kolaboratif (Blair \& Serafini, 2014). Pengguna dapat menyimpan, mengkliping, menandai dan mengorganisasi materi-materi pembelajaran yang berasal dari media online seperti website dan Youtube.

Studi cross sectional oleh Kani (2017) mengenai penggunaan Evernote sebagai alat konsultasi penelitian mahasiswa di sebuah perguruan tinggi di US menemukan bahwa Evernote bermanfaat dalam mendokumentasikan artikel, mengorganisasi informasi dan mempermudah pencarian kata kunci selama proses konsultasi. Selain itu, aplikasi ini mampu meningkatkan interaksi dosen dan mahasiswa. Selain itu, persepsi mahasiswa terhadap penggunaan mobile apps cukup baik karena miliki keunggulan yaitu konektivitas, portabilitas dan kenyamanan yang baik (Aghaee \& Larsson, 2013). Berdasarkan potensinya sebagai platform e-learning, evaluasi terhadap Evernote perlu dilakukan khususnya terkait tingkat usabilitas dan kepuasan mahasiswa dalam menggunakan Evernote pada area pendidikan keperawatan.

\section{METODE PENELITIAN}

Penelitian ini merupakan penelitian kuantitatif dengan metode cross sectional. Subjek penelitian adalah 139 mahasiswa keperawatan Fakultas Keperawatan di Universitas Padjadjaran. Penelitian dilakukan pada bulan Juni-Juli 2017. Responden dipilih menggunakan metode purposive sampling dengan kriteria inklusi yaitu mahasiswa keperawatan aktif, bersedia berpartisipasi sebagai responden penelitian, bersedia mengikuti proses pembelajaran menggunakan platform Evernote hingga selesai, bersedia mengisi kuesioner usabilitas dan kepuasan 
Tingkat Usabilitas dan Kepuasan Evernote sebagai Flatform E-Learning untuk Mata Kuliah Ilmu Dasar Keperawatan (Ryan Hara Permana)

terhadap platform secara lengkap. Kriteria ekslusi, yaitu mahasiswa yang tidak menyelesaikan proses pembelajaran, dan tidak mengisi kuesioner dengan lengkap.

Responden yang setuju untuk berpartisipasi mengikuti penelitian diberi tautan berisi panduan pembelajaran dan panduan berlangganan dalam online course Ilmu Dasar Keperawatan. Setelah responden berlangganan mengikuti online course tersebut, mereka kemudian menerima note berisi materi yang dikirim secara otomatis dan serial. Para siswa mengikuti proses pembelajaran sesuai dengan arahan instruksional yang disediakan dalam panduan belajar. Mereka juga melakukan interaksi dan latihan soal atau evaluasi secara daring pada setiap subbab.

Sebuah online course terbuka versi trial berjudul Ilmu Dasar Keperawatan dikembangkan untuk memberikan pengalaman belajar daring untuk mahasiswa keperawatan tingkat pertama, kedua dan ketiga. Online course ini berisi satu note yang terdiri dari panduan belajar, dan tiga catatan materi. Note adalah nama file dalam aplikasi Evernote. Pemanfaatan Evernote sebagai platform e-learning terinspirasi oleh Dotto (2015). Dalam penelitian ini, penggunaan Evernote dimodifikasi dengan mengintegrasikan aplikasi lainnya seperto MailChimp, dan Google Applications, diantaranya Google+, Google Form, Google Docs dan Google Sheet. Aplikasi MailChimp digunakan untuk mengelola sistem pembelajaran otomatis termasuk surel balasan, feedback, dan berlangganan secara otomatis, antara dosen dan mahasiswa. Google+ digunakan sebagai platform yang menyediakan ruang diskusi dalam forum tertutup. Selain itu, Google Form digunakan untuk tes daring dan sebagai alat bagi mahasiswa untuk mengisi kuesioner penelitian setelah menyelesaikan online course.

Kuesioner usabilitas dan kepuasan penggunaan aplikasi diadaptasi dari PostStudy System Usability Questionnaire (PSSUQ) yaitu instrumen evaluasi usabilitas dan kepuasan penggunaan perangkat lunak yang diadopsi dari penelitian terdahulu oleh Frughling dan Lee (2005). Kuesioner terdiri 24 pertanyaan dan dirancang menggunakan skala Likert dengan skala berkisar $0=$ 'sangat tidak setuju' hingga $4=$ 'sangat setuju'. Kuesioner tersebut telah melalui proses translate dan back translate untuk menguji validitasnya. Selain itu, juga telah dilakukan uji reliabilitas dengan metode Spearman Brown. Hasil uji menunjukkan bahwa kuesioner memiliki reliabilitas yang tinggi dengan faktor analisis Cronbach's Coefficient Alpha yaitu 0,933. Kuesioner didistribusikan secara daring dengan Google Form melalui media sosial.

\section{ANALISIS DATA}

Analisa data dilakukan dengan menentukan rata-rata (mean) tiap item, dan menetapkan mean item dalam satu kategori. Lalu nilai tersebut dikonveresikan ke dalam persen (\%) dengan membaginya dengan nilai maksimal rentang (4) dikalikan $100 \%$.

\section{HASIL PENELITIAN}

Berdasarkan hasil kuesioner yang telah diisi oleh 139 mahasiswa keperawatan dari Fakultas Keperawatan, Universitas Padjajaran, data menunjukkan bahwa mayoritas responden adalah perempuan dengan jumlah 126 responden $(90,65 \%)$ dan hanya tiga belas mahasiswa laki-laki $(9,35 \%)$. Usia responden berkisar antara 18-22 tahun. 


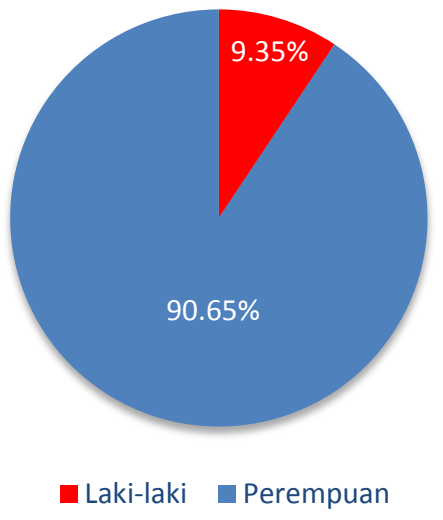

Gambar 1. Distribusi Responden Berdasarkan Jenis Kelamin

Tabel 1.

Distribusi Tingkat Kepuasan dan Usabilitas Berdasarkan Kategori

\begin{tabular}{lllll}
\hline $\begin{array}{l}\text { N } \\
\text { o. }\end{array}$ & $\begin{array}{l}\text { Kategori } \\
\text { Pertanyaan }\end{array}$ & $\begin{array}{l}\text { Nomor } \\
\text { Pertanya } \\
\text { an }\end{array}$ & $\begin{array}{l}\text { Rata } \\
\text {-rata }\end{array}$ & $\begin{array}{l}\text { Konver } \\
\text { si }\end{array}$ \\
\hline 1 & $\begin{array}{l}\text { Desain dan } \\
\text { tata letak }\end{array}$ & $1-3$ & 3.08 & $77 \%$ \\
2 & Usabilitas & $4-7$ & 2.77 & $69.2 \%$ \\
3 & $\begin{array}{l}\text { Kemudahan } \\
\text { penggunaan }\end{array}$ & $8-11$ & 2.59 & $64.7 \%$ \\
4 & $\begin{array}{l}\text { Kemudahan } \\
\text { belajar }\end{array}$ & $12,13,24$ & 2.58 & $64.5 \%$ \\
5 & $\begin{array}{l}\text { Kepuasan } \\
\text { rata-rata }\end{array}$ & $14-16$ & 2.56 & $61.5 \%$ \\
6 & $\begin{array}{l}\text { Hasil belajar } \\
\text { dan }\end{array}$ & $17-21$ & 2.26 & $56.4 \%$ \\
& $\begin{array}{l}\text { Keinginan } \\
\text { Menggunaan }\end{array}$ & & & \\
7 & $\begin{array}{l}\text { Kembali } \\
\text { Reliabilitas } \\
\text { sistem }\end{array}$ & $22-23$ & 2.26 & $56.5 \%$ \\
\hline
\end{tabular}

Berdasarkan Tabel 1, kategori pertanyaan 'Desain dan Tata Letak' yang terdiri atas tiga pertanyaan tentang antarmuka dan organisasi informasi dalam Evernote, diketahui bahwa skor rata-rata adalah 3,08 (77\%). Melalui pertanyaan yang terkait dengan 'Usabilitas' aplikasi, diperoleh data bahwa skor rata-rata adalah 2,77 (69,2\%). Dalam kategori 'Kemudahan Penggunaan' memperoleh rerata 2,59 (64,7\%) bermakna bahwa aplikasi cukup mudah digunakan. Rerata pada kategori 'Kemudahan Belajar' yaitu 2,58 (64,5\%), berarti bahwa aplikasi ini cukup baik dalam membantu mahasiswa belajar dengan lebih mudah. Data dalam kategori 'Hasil Belajar dan Keinginan Menggunaan Kembali' aplikasi memiliki rerata 2,26 (56,4\%) berarti bahwa pengaruh aplikasi terhadap hasil belajar dan keinginan untuk menggunakan kembali aplikasi ini dinilai kurang. Selain itu, aspek 'Reliabilitas Sistem' memiliki nilai rata-rata 2,26 (56,5\%), artinya reliabilitas sistem dinilai kurang baik.

\section{PEMBAHASAN}

Hasil penelitian menunjukkan bahwa skor rata-rata adalah 3,08 dan itu berarti bahwa $77 \%$ dari semua responden puas dengan antarmuka aplikasi web Evernote. Ini karena Evernote memiliki antarmuka yang modern, minimalis, dan mudah digunakan. Aplikasi ini dapat diakses melalui web, melalui web seluler, aplikasi Android atau aplikasi iOS. Penggunaan Evernote sebagai platform elearning dalam penelitian ini terintegrasi dengan aplikasi Google seperti Google+ dan Google Form. Penggunaan aplikasi Google memiliki kekurangan karena pengguna harus membuka tautan baru dan berpindah dari satu platform ke platform lain. Namun, platform elearning yang dibangun dari beberapa platform berbeda memiliki beberapa kelebihan dibandingkan hanya menggunakan satu platform karena pengguna dapat memiliki pengalaman yang berbeda sehingga mereka tidak akan merasa bosan dengan tata letak monoton (Dotto, 2015). Misalnya, penggunaan Google+ sebagai media untuk interaksi daring memberikan pengalaman diskusi media sosial seperti yang disediakan Google+ dalam fitur komunitasnya.

Hasil survei tentang usabilitas aplikasi diperoleh nilai rata-rata 2,77 atau 69,2\%. Ini menunjukkan bahwa responden juga puas dengan fungsi aplikasi ini dalam 
Tingkat Usabilitas dan Kepuasan Evernote sebagai Flatform E-Learning untuk Mata Kuliah Ilmu Dasar Keperawatan (Ryan Hara Permana)

pembelajaran online. Ardito et al. (2004) menyatakan bahwa platform e-learning yang dianggap memberikan pengalaman belajar yang memuaskan harus memiliki fitur yang sesuai dengan kebutuhan, menarik dan memiliki struktur materi yang baik.

Dalam kategori 'Kemudahan Penggunaan' ada $64,7 \%$ responden menjawab puas dengan kemudahan menggunakan menu dalam aplikasi ini dan 64,5\% dari semua responden menganggap bahwa aplikasi ini juga mempermudah mereka untuk belajar. Jawaban-jawaban ini menunjukkan bahwa penggunaan Evernote dalam pembelajaran online memiliki potensi sangat besar dan perlu penelitian lebih lanjut. Penggunaan Evernote dalam e-learning telah berkembang pesat termasuk digunakan dalam Massive Open Online Course (MOOC) (Kukharenko, 2013) dan e-learning di sekolah dasar (Kearney \& Maher, 2013).

Dalam kategori 'Hasil Belajar dan Keinginan Menggunakan Kembali' dinilai kurang baik. Hal ini dapat terjadi karena aplikasi ini adalah aplikasi baru yang digunakan dalam pembelajaran daring oleh mahasiswa sehingga mereka masih memiliki kesadaran yang kurang tentang manfaat menggunakan Evernote. Padahal Evernote menawarkan berbagai kemudahan diantaranya akses tanpa batas sehingga mereka dapat belajar di mana saja selama ada sambungan internet, memperbarui konten yang dapat dilakukan secara berkala, fitur kolaborasi, dan layanan freemium atau gratis untuk penggunaan terbatas. Hasil ini wajar karena durasi online course Ilmu Dasar Keperawatan hanya dibuka selama satu bulan, dan tanpa ada pelatihan khusus sebelumnya bagi mahasiswa. Selain itu, online course ini bersifat trial artinya kegiatan belajar tidak terintegrasi dengan kurikulum dan tidak berdampak pada pencapaian akademik mahasiswa. Oleh karena itu, dampak Evernote belum dapat dirasakan secara langsung dalam peningkatan hasil belajar.

Aspek 'Realibilitas Sistem' dinilai oleh responden rata-rata dengan nilai 2,26 atau $56,5 \%$. Ini menunjukkan bahwa responden kurang puas dengan reliabilitasnya. Ini bukan karena sistem Evernote bermasalah, tetapi karena koneksi internet yang digunakan oleh responden tidak selalu stabil. Sebagai bukti, dengan mengakses situs web http://status.evernote.com/, dapat dilihat bahwa Evernote melakukan pemeliharaan berkala setiap minggu pada Rabu 18:00 Waktu Pasifik atau Kamis pukul 08.00 pagi. Pemeliharaan berkala adalah hal penting yang dilakukan oleh situs web sehingga sistem selalu responsif dan dapat diandalkan bila digunakan oleh konsumen (Laisheng \& Zhengxia, 2011).

\section{SIMPULAN DAN SARAN}

Evernote diminati oleh mahasiswa keperawatan namun mereka belum dapat melihat kemanfaatannya dalam belajar karena penelitian dilakukan pada mata kuliah online versi trial. Evernote memiliki tingkat usabilitas dan kepuasan yang baik untuk digunakan sebagai platform pembelajaran online, terutama $\mathrm{di}$ institusi pendidikan keperawatan. Tingkat usabilitas dan desain dan tata letak dianggap cukup baik. Aplikasi juga mudah digunakan dan memudahkan mahasiswa belajar. Mahasiswa juga merasa puas belajar dengan Evernote. Reliabilitas sistem aplikasi tergantung pada kualitas jaringan internet pengguna. Perlu penelitian lebih lanjut dengan implementasi Evernote mata kuliah online yang terintegrasi dengan kurikulum dan didukung dengan tahap persiapan yang komprehensif. Khususnya untuk menghasilkan data objektif mengenai pengaruh aplikasi terhadap hasil belajar dan 
keinginan mahasiswa untuk menggunakan kembali aplikasi ini.

\section{UCAPAN TERIMA KASIH}

Terimakasih kepada Hibah Internal Universitas Padjadjaran tahun 2017 atas dukungan fasilitas subscription aplikasi Evernote selama satu tahun untuk kepentingan penelitian ini.

\section{REFERENSI}

Aghaee, N., \& Larsson, K. (2013). Students' perspectives on utility of mobile applications in higher education. In International Conference on Mobile Web and Information Systems (pp. 44 56). Springer.

AIPNI. (2017). AIPNI members in 2017. Retrieved from http://aipniainec.com/id/anggota_list//15

Ardito, C., De Marsico, M., Lanzilotti, R., Levialdi, S., Roselli, T., Rossano, V., \& Tersigni, M. (2004). Usability of elearning tools. In Proceedings of the working conference on Advanced visual interfaces (pp. 80-84). ACM.

Blair, R., \& Serafini, T. M. (2014). Integration of education: Using social media networks to engage students. Systemics.

Cybernetics,

and Informatics, 6(12).

Cho, V., Cheng, T. C. E., \& Lai, W. M. J. (2009). The role of perceived userinterface design in continued usage intention of self-paced e-learning tools. Computers \& Education, 53(2), 216227.

Coursaris, C. K., \& Kim, D. J. (2011). A meta-analytical review of empirical mobile usability studies. Journal of Usability Studies, 6(3), 117-171.

Dotto, S. (2015). Using Evernote for Course Delivery. Retrieved February 1, 2017, from https://www.evernote.com/shard/s85/sh/ 5436fd39-69ed-46b0-88db- 0bca9da0048d/ca16216b177b6bd2?inf contact_key=fa433c059585eaf36165bb 1036d1a145d1049245107c5b509a2804 9656f0fe32

Frughling, A., \& Lee, S. (2005). Assessing the Reliability, Validity and Adaptability of PSSUQ. AMCIS 2005: Proceedings of the 11th Americas Conference on Information Systems, 2394-2402.

Kani, J. (2017). Evernote in the research consultation: a feasibility study. Reference Services Review, 45(1), 6778 .

Kearney, M., \& Maher, D. (2013). Mobile learning in maths teacher education: Using iPads to support pre-service teachers' professional development. Australian Educational Computing, 27(3), 76-84.

Kemenristekdikti. (2016). Sistem Pembelajaran Daring (SPADA) Indonesia. Retrieved May 3, 2018, from http://kuliahdaring.dikti.go.id/s/

Kukharenko, V. (2013). Designing Massive Open Online Courses. In ICTERI (pp. 273-280).

Laisheng, X., \& Zhengxia, W. (2011). Cloud computing: a new business paradigm for E-learning. In Measuring Technology and Mechatronics Automation (ICMTMA), 2011 Third International Conference on (Vol. 1, pp. 716-719). IEEE.

Maulana, A., \& Siswandini, N. (2018). Kemenristekdikti Luncurkan Sistem Pembelajaran Perguruan Tinggi Berbasis Daring. Retrieved May 3, 2018, from http://www.unpad.ac.id/2018/05/kemen ristekdikti-luncurkan-sistempembelajaran-perguruan-tinggiberbasis-dalam-jaringan/

Singh, H. (2003). Building effective blended learning programs. Educational Technology-Saddle Brook Then Englewood Cliffs NJ-, 43(6), 51-54. 